\title{
POSSIBLE RECENT OCCURRENCE OF GRIZZLY IN MANITOBA
}

\section{by R. W. Sutron, Manitoba Museum of Man and Nature, Winnipeg}

The only tangible evidence of grizzly in Manitoba is a single skull ploughed up at Austin, Manitoba by Thomas Carruthers in the 1940's and presented to the museum. It is aged and weathered, and obviously represents a time long gone. Recent correspondence with Mr. J. D. Robertson, Regional Supervisor, Renewable Resources, Dauphin, Manitoba has brought to light what may be a more recent occurrence of grizzly in this province.

The locality is the old Ethelbert Trail in Duck Mountain, approximately Sec. 20, Twp. 24, R. 23 W. In the spring of 1923, Mr. Robertson's father, an experienced woodsman, in company with Mr. Garnet Lacey, was trapping black bears for pelts. In one trap they found a black bear dead and partially eaten. Tracks indicated that two large bears had been present during the attack on the trapped animal. Bearing in mind that the animals appeared to be of unusual size, the elder Robertson re-arranged the set. This he did by attaching a green birch clog "as large as he could carry", and by omitting the small peg usually inserted to lessen the strike of the trap jaws.

On the following day the trap and clog were missing, and the two men took up the trail. Eventually the bear was located. While the men circled, seeking a clear shot in the heavy bush; the bear, though hampered by the heavy clog, rushed them repeatedly. After almost an hour of cautious circling by the men, and steady pursuit by the bear, a clear head shot was offered and the animal was at once despatched.

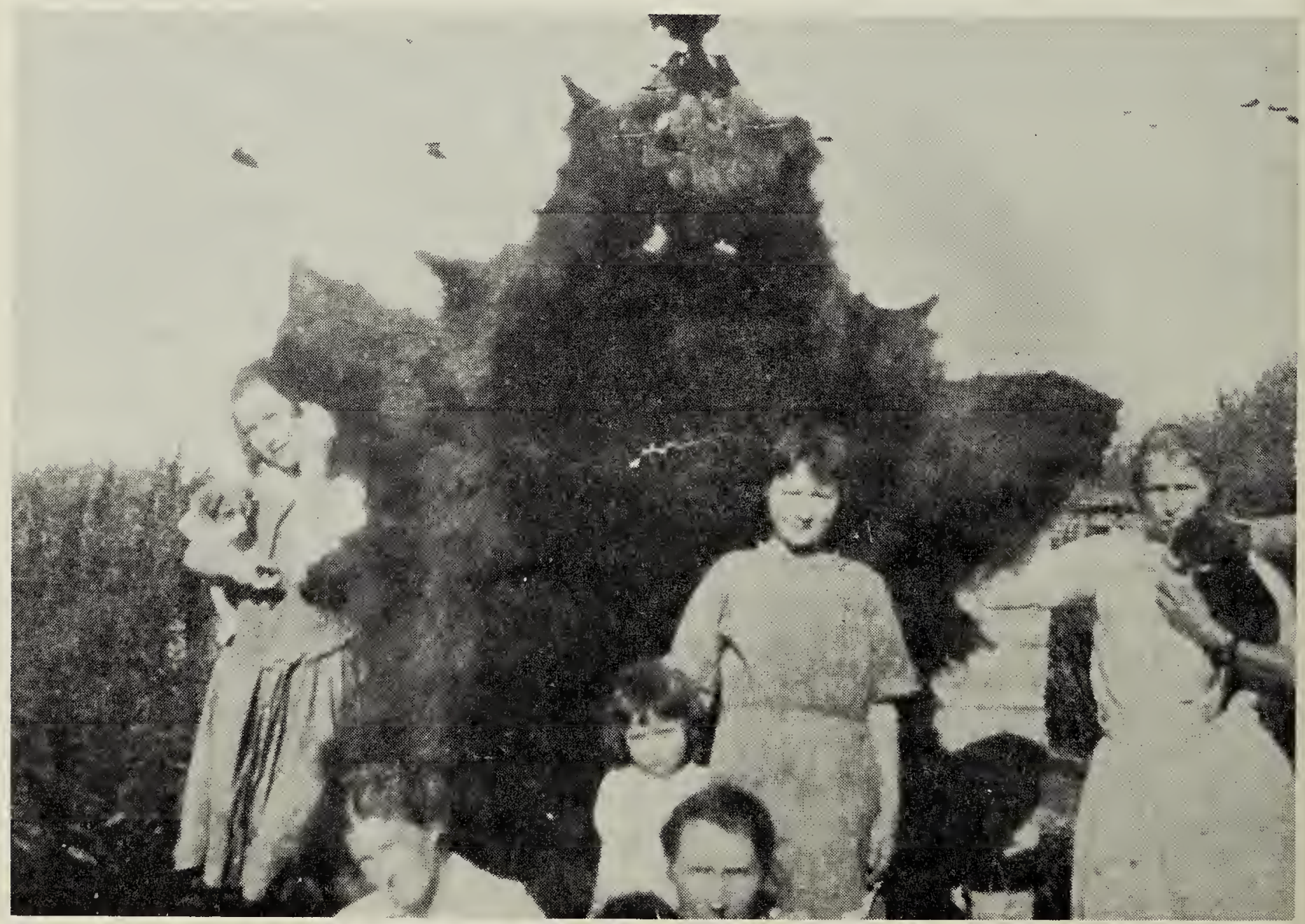


The elder Robertson, who had trapped hundreds of black bears, was so impressed by the animal that he brought home not only the pelt but the skull, and a forepaw. J. D. Robertson, our present correspondent, clearly recalls his father showing the youngsters the long claws of the bear and the massive skull, and comparing them with those of the black bear with which they were so familiar. He also showed the trap which, though considered too powerful for black bear, had not broken the paw of the trapped animal, and had been twisted out of alignment.

Examination of the bear indicated that, though impressively large, it was the smaller of the two originally tracked. On the following day $\mathrm{Mr}$. Lacey, and subsequently the elder Robertson, located the larger bear. Heavy brush, and the obvious size and potential of the animal, persuaded them not to risk a shot, and they left if unharmed.

Mr. Robertson points out that though the bear was not "grizzled" it was so different from a black bear that his father retained the pelt for some time as a personal memento.

Grizzly in Manitoba as late as 1923 ? We still can't be certain, but the evidence warrants close examination. Phil and Jed Reader of The Pas, in personal correspondence with J. D. Robertson, mention receiving reports of grizzly in the Pasquia hills in the 1920's.

\section{PRAIRIE NEST RECORDS SCHEME}

Contributors to the Prairie Nest Records Scheme are reminded to send their nest record cards to Dr. Robert W. Nero, Manitoba Museum of Man and Nature, Winnipeg 2. If you have not previously contributed to this scheme but are interested in keeping good records of individual nests or colonies of nests write to Dr. Nero for advice and information about the scheme.
IDENTIFICATION OF BISON SKULLS

by Fred Schutz, Buffton, Alberta

Regarding the photograph of the buffalo skulls sent in by Mrs. G. Knudsen of Porcupine Plain, Manitoba, and published in the September, 1967 issue of the Blue Jay: Any skull measuring 28 inches would very likely be that of the Wood Bison (Bison biscn athabascae). It is too large to belong to a Plains Bison (Bison bison bison).

Any buffalo skull - or skeleton brought to light today should be carefully preserved as another link with our ever receding past; as a reminder that scarcely more than 100 years ago, $60,000,000$ buffalo, by reliable estimate, roamed over North America. Quite apart from this, a large bison skull may occasionally be found that is old enough to be of considerable value to paleontologis.ts, archaeologists and historians. Several species of bison, all but two of them long extinct, have left skeletal remains which turn up with varying frequency and in various stages of preservation. Identification of prehistoric types is often difficult, especially for the layman. To be able to hazard even an educated guess as to the age and species of a bison skull, it is necessary to know something about the early history of the buffalo on this continent, a subject about which much remains to be learned, and about which very little was known until a few short years ago.

It all began with a monstrous animal named Bison latifrons which came to North America via the Behring Land Bridge some 500,000 years ago. A latifrons bull was the size of a small elephant and carried horns measuring seven feet between the tips. Along with other giant mammals of times past, the bison diminished in size down over the millenia. Bison crassicornis is the name given to one of these smaller species. Several of the skulls identified as crassicornis have been found in Alaska and seven in Alberta. Crassicornis has been extinct for many thousands of years, 